\title{
Estratégias de exploração de vizinhança com GPU para problemas de otimização
}

\author{
Rodolfo Araujo ${ }^{1}$, Igor Machado Coelho ${ }^{1}$, Leandro Marzulo ${ }^{1}$ \\ ${ }^{1}$ Universidade do Estado do Rio de Janeiro
}

\begin{abstract}
Optimization problems have big importance in the industry field, from production management to production outflow and product transportation. Many problems of inte-rest are classified as NP-Hard, so there is no known algorithm to find the exact solution in a polinomial time. Therefore heuristic strategies with the ability to escape from poor quality local optima (meta-heuristics) are generally employed. In general, the local search is the most costly, in computational time, phase of a meta-heuristic, becoming mandatory a good use of the available resources. The parallel processing of neighborhood strategies is implemented at the fine grain level through GPU processing and coarse grain through multi-core processing and network processing, the combination of the two level parallelization in a heterogeneous environment for von Neumann architectures and dataflow.
\end{abstract}

Resumo. Problemas de otimização são de grande importância para diversos setores da indústria, desde o planejamento de produção até escoamento e transporte de produtos. Diversos problemas de interesse se enquadram na classe NP-Difícil, sendo desconhecidos algoritmos para resolvê-los de forma exata em tempo polinomial. Assim, estratégias heurísticas com capacidade de escapar de ótimos locais de baixa qualidade (meta-heurísticas) são geralmente empregadas. A busca local é, em geral, a etapa mais custosa, em termos de tempo computacional, do processo de uma meta-heurística. Desta forma torna-se muito importante fazer bom uso dos recursos nela utilizados. Esta dissertação estuda o emprego de múltiplas estratégias de vizinhança utilizadas paralelamente para explorar um espaço de vizinhança maior e com melhor aproveitamento dos recursos computacionais. O processamento paralelo das estratégias de vizinhança é implementado em nível de grão fino, através de processamento em GPU, e grão grosso, por meio de processamento multi core e processamento em rede, sendo os dois níveis combinados num ambiente heterogêneo, para arquiteturas von Neumann e dataflow. 